\title{
Occipital meningoencephalocele in a preterm neonate
}

\author{
Prem Arora, Swati Mody, Vaneet Kumar Kalra, Dima Altaany, Monika Bajaj
}

The Carman and Ann Adams Department of Pediatrics, Division of Neonatal-Perinatal Medicine, Wayne State University School of Medicine, Detroit Medical Center, Children's Hospital of Michigan \& Hutzel Women's Hospital, Detroit, Michigan, USA

Correspondence to Dr Prem Arora, premarora96@yahoo.com, premarora1112@gmail.com

\section{DESCRIPTION}

A preterm (33 weeks) male neonate was born to a 34-year-old mother by caesarean section. The mother had a history of chronic hypertension, type 1 diabetes mellitus, stroke and asthma. Her medications included enoxaparin, insulin, nifedipine, methyldopa, inhaled albuterol and inhaled corticosteroids. She received regular prenatal care. The obstetric ultrasound done at 21 weeks of gestation revealed an occipital encephalocele, measuring $\sim 3.3 \times 2.0 \times 2.5 \mathrm{~cm}$ in size and protruding through a $0.95 \mathrm{~cm}$ cranial defect in the occipital area. The baby had a spontaneous cry at birth with Apgar score of 9 and 9 at 1 and $5 \mathrm{~min}$, respectively. His birth weight was $1650 \mathrm{~g}$ (10th-25th percentile). On physical examination, he was found to have a large $(\sim 5 \times 4 \times 5 \mathrm{~cm}$ in size $)$, soft, skincovered mass protruding from the occipital area (figure 1). MRI of the head done on day 3 of life revealed a large defect in the occipital bone with extra-axial fluid, meninges, brain matter and ventricles entering the defect (figure 2). A diagnosis of occipital meningoencephalocele

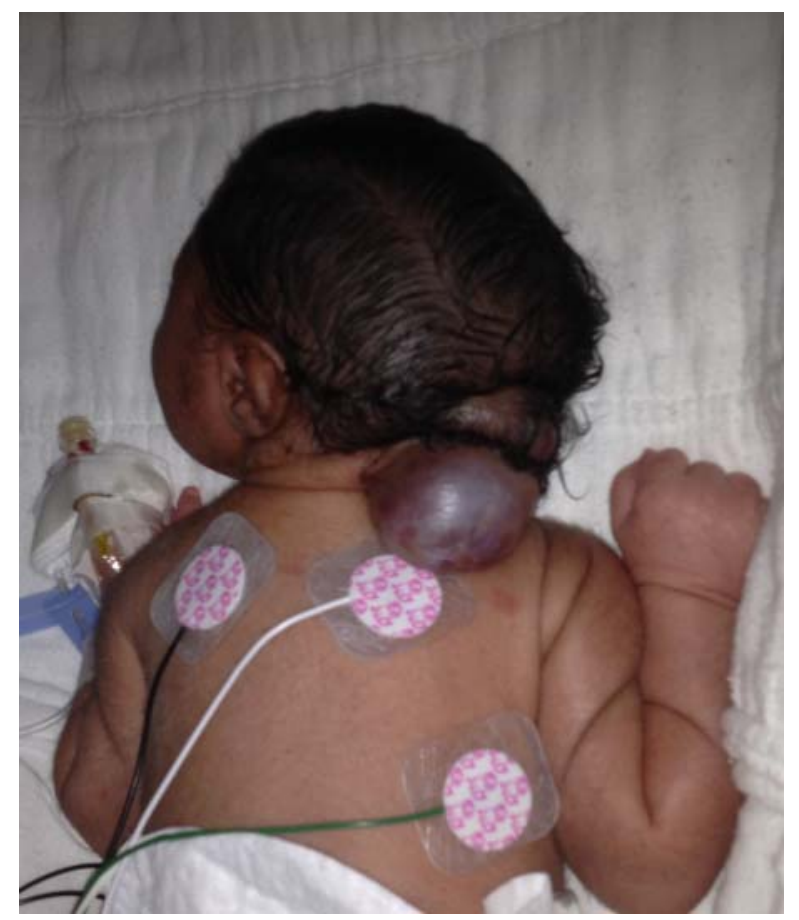

Figure 1 Large, soft, skin-covered mass protruding from the occipital area. was made. Reparative surgery was performed by the neurosurgery team at the age of 35 days. Postoperatively, he had uneventful recovery and was discharged home on full oral feeds on postoperative day 4. Encephalocele is a rare type of neural tube defect with an incidence of 1-4 cases per 10000 live births. ${ }^{1}$ Meningoencephalocele develops after the failure of normal midline fusion of cranial neural tube leading to a congenital bony defect through which brain and meninges herniate. Approximately $75 \%$ of the encephaloceles are located in the occipital region. ${ }^{1}$ They usually contain a degenerative cerebral cortex, which is often excised during reparative surgery. If the sac contains normal brain tissue, techniques such as 'expansion cranioplasty' and 'ventricular volume reduction' have been described to preserve the herniated brain. ${ }^{2} 3$ However, in most of the cases, herniated brain tissue is excised.

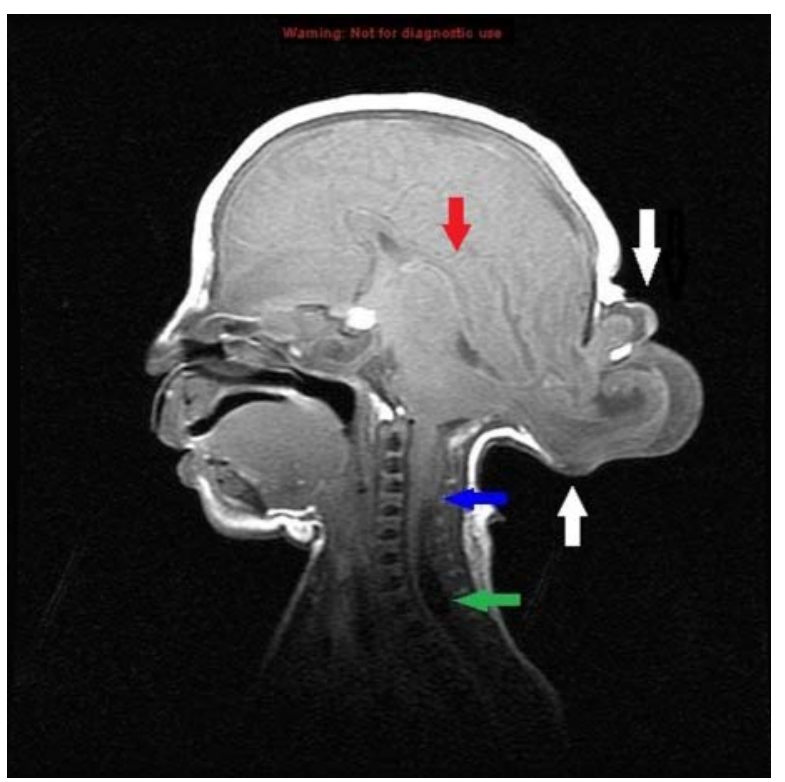

Figure $2 \mathrm{MRI}$ of the head (sagittal T1-weighted midline image) showing a large occipital meningoencephalocele (white arrows) with herniation of the occipital lobe, occipital horn of the lateral ventricle and small dysmorphic cerebellar tissue into the sac. Other findings include dysgenetic corpus callosum with absent splenium (red arrow), small posterior fossa with dysmorphic cerebellar hemispheres and non-visualised fourth ventricle, herniation of the medulla into the cervical region with cervicomedullary kink (blue arrow) and a small syrinx in the cervicothoracic region (green arrow). 


\section{BMJ Case Reports}

\section{Learning points}

- Occipital meningoencephalocele is a very rare type of neural tube defect.

- Preoperative MRI provides useful information to assess prognosis and plan the surgical management of occipital meningoencephalocele.

- Despite the surgical management, prognosis remains poor with an extremely high risk of mortality and morbidities including mental and/or physical impairment.

\section{Competing interest None.}

Patient consent Obtained.

\section{REFERENCES}

1. Sandler MA, Beute GH, Madrazo BL, et al. Ultrasound case of the day. Occipital meningoencephalocele. Radiographics 1986;6:1096-9.

2. Gallo AE Jr. Repair of giant occipital encephaloceles with microcephaly secondary to massive brain herniation. Childs Nerv Syst 1992;8:229-30.

3. Oi S, Saito M, Tamaki N, et al. Ventricular volume reduction technique-a new surgical concept for the intracranial transposition of encephalocele. Neurosurgery 1994;34:443-7; discussion 448.

This pdf has been created automatically from the final edited text and images.

Copyright 2012 BMJ Publishing Group. All rights reserved. For permission to reuse any of this content visit http://group.bmj.com/group/rights-licensing/permissions.

BMJ Case Report Fellows may re-use this article for personal use and teaching without any further permission.

Please cite this article as follows (you will need to access the article online to obtain the date of publication).

Arora P, Mody S, Kalra VK, Altaany D, Bajaj M. Occipital meningoencephalocele in a preterm neonate. BMJ Case Reports 2012;10.1136/bcr-2012-006293, Published XXX

Become a Fellow of BMJ Case Reports today and you can:

- Submit as many cases as you like

- Enjoy fast sympathetic peer review and rapid publication of accepted articles

- Access all the published articles

- Re-use any of the published material for personal use and teaching without further permission

For information on Institutional Fellowships contact consortiasales@bmjgroup.com

Visit casereports.bmj.com for more articles like this and to become a Fellow 